FREP

1,2

Received 1 October 2021 Revised 23 October 2021 Accepted 28 October 2021

\section{Restrictive or expansive? European Investment Bank's challenge to equipoise climate finance with post-pandemic boost}

\author{
Helen Kavvadia \\ Institute of Political Science, University of Luxembourg, Luxembourg, Luxembourg
}

\begin{abstract}
Purpose - Unique among European Union (EU) economic governance entities and multilateral banks, the European Investment Bank (EIB) possesses a dual nature, as an EU body and a bank. The EIB has been ever evolving to adapt to policy and market developments and to reflect the geo-economic landscape. In 2019, in association with the EU's Green Deal, the bank announced its metamorphosis into a "Climate Bank," ending its fossil fuel lending after 2021. Additionaly, upon the outbreak of coronavirus disease 2019 (COVID-19) and its attendant health and economy crisis, EU decision-makers have solicited the bank to support both urgent needs for tackling and countering the spread of the disease and the post-pandemic economic recovery. Nevertheless, devastated economic actors in need of assistance fall within many sectors, including some less green ones.

Design/methodology/approach - This article is grounded on agency theory for developing a generic stakeholder framework, which is then subsequently applied in investigating the EIB, in interaction with its main stakeholders.

Findings - This article investigates the EIB stakeholders in pursuing these two seemingly contradictory objectives of exclusively restricting its activity to green funding and expanding its action for achieving a broad impact in the real economy. By exploring this tension, the article argues that by prioritizing the post-COVID restart, the EIB risks to deviate from its strict green commitment.

Practical implications - The analysis of the EIB's divergent stakeholder stances demonstrates some ambivalence in future EIB activity in an effort to equipoise climate finance with a post-pandemic boost. The same ambivalence might equally occur with other major economic governance actors. The stakeholder framework developed and applied in the case of the EIB can be useful for studying also the stakeholder dynamics of other organizations.

Social implications - The analysis demonstrates a tension between selective climate-related funding for "building back better" and the need for a wide broaching of countercyclical stimulus, with implications for economic and social actors alike.

Originality/value - The approach is novel, as it develops a new analytical framework for understanding stakeholder dynamics and tests it empirically on the EIB. This constitutes the first study of EIB stakeholder management.
\end{abstract}

Keywords Stakeholder governance, European investment bank, EU governance and sustainability, PostCOVID pandemic economic recovery

Paper type Research paper

(c) Helen Kavvadia. Published in Fulbright Review of Economics and Policy. Published by Emerald Publishing Limited. This article is published under the Creative Commons Attribution (CC BY 4.0) licence. Anyone may reproduce, distribute, translate and create derivative works of this article (for both commercial and non-commercial purposes), subject to full attribution to the original publication and authors. The full terms of this licence may be seen at http://creativecommons.org/licences/by/4.0/ legalcode

This paper was presented in a rough form at the 2021 SASE Conference, held from 2 to 5 July 2021, remotely at panel TH04-Development Finance in a Changing Global Context on July 5, 2021. The author would like to thank the discussants Daniel Mertens and Matthias Thiemann, as well as the participants for their useful comments.

This research did not receive any specific grant from funding agencies in the public, commercial, or not-for-profit sectors. 


\section{Introduction}

Upon stabilizing the economy in the aftermath of the international financial crisis and the Great Recession of the late 2000s, international attention turned to measures to counter the long-looming climate change threatening humanity. The European Union (EU) embarked on a political, economic and socio-ecological transformational effort aligned with the Paris Agreement to "achieve climate neutrality by 2050" (EC, 2019b, p. 4). Focusing on decarbonization, Europe relied on the experience gained through its fight against the recession in the aftermath of the Global Financial Crisis in 2008 to couple the transformational climate process with growth stimulus. Utilizing partly analogous political and economic governance initiatives and actors, while in parallel topping them with made-to-purpose policies, the EU proposed a bolder response to achieve both climate neutrality and economic growth. These two objectives appear to many to diverge at first glance, including degrowth apologists, even after second thoughts.

Nonetheless, in a syncretism effort, the EU elaborated the Next Generation EU (NGEU), its largest "stimulus initiative ever" (EC, 2021) of 2,018 trillion euros, which locks into the European Green Deal (EGD) (EC, 2019b) to rebuild a post-coronavirus disease 2019 (COVID19) Europe greener, more digital and more resilient. The initiative is far-reaching and comprehensive, benefiting from inputs along two axes. First, the EU proliferates the skill- and tool-set devised to guide Europe back into a growth track after the recession in the aftermath of the Global Financial Crisis. Second, the EU builds on and extends the EU climate-related political economy set-up and future activity, an area in which Europe had already gained international recognition as a global leader in climate-related issues within and beyond its borders (Barnes \& Hoerber, 2013; Torney, 2019; Mišík \& Oravcová, 2021). Moreover, the EGD exemplifies the congruence of both appropriateness and consequentialism (Dyrhauge \& Kurze, 2021) to mobilize actors by both normative and instrumental rationality means, respectively. In this vein, it encompasses a wide array of interlinked policy areas and ancillary mechanisms, with an enabling finance package, for shifting resources and attaining EU climate targets.

Similarly, to pass policy initiatives that include a funding element, the EU has turned anew to its financial arm, the European Investment Bank (EIB), to complement its budget resources with additional loan funding. To make a point regarding the dynamic theory of public banks (Marois, 2021a, b), the EIB has been historically adjusting to ever-changing European policy priorities and EU calls. Since its establishment, the EU's financial arm has been shifting from its initial remit in regional development in the mid-1950s to the making of markets in the mid1980s (Clifton, Diaz-Fuentes, \& Revuelta, 2014). Subsequently, the EIB moved from development and integration to investment in the 1990s (Clifton, Diaz-Fuentes, \& Gómez, 2018), evolving from a mono-focal activity to a multi-focal activity for smart, sustainable and inclusive growth in the 2000s (Kavvadia, 2020). This pattern changed abruptly in November 2019 when the EIB turned to a quasi-mono-focal area of activity again, following its selfanointment to become the first international climate bank, pre-empting in its climateeagerness even the EU official presentation of the EGD, which the EIB is supposed to serve. Nonetheless, the EIB's climate-related "interventionist market-shaping" (Clifton, DiazFuentes, \& Howarth, 2021, p. 25) aspirations were intercepted by the outbreak of the COVID19 pandemic only three months later. Having hardly announced its new, selective, and hence restrictive climate strategy and energy-lending policy-ending fossil fuel financing after 2021 while doubling its climate-lending target from $25 \%$ in 2018 to $50 \%$ by 2025 (EIB, 2019)-the EIB was called on again to support European efforts to halt the pandemic, to counter its dramatic economic impact resulting from several successive lockdowns and to relaunch growth in the post-pandemic era.

While the EIB's restrictive climate "pivot" has been greeted by climate-sensitive and cognizant actors, who even pushed for a more restrictive and stringent transformative

\section{European Investment Bank}


FREP

1,2

lending policy with a long-term horizon (CB, 2020a, b, c, 2021), the generalized and unprecedented magnitude of the social and economic hazards engendered by the pandemic demanded multi-focal and expansive short-to medium-term activity broaching across existing economic undertakings. Although the NGEU-which the EIB intends to supportmaintained the green social and economic transformation at the core of its COVID-19 response measures, it widened the scope of its policy areas. Beyond climate, the NGEU equally includes the EU's digital transformation for strategically integrating the European economies in a single digital market and providing in this manner further economic stimulus. The stimulus is expected to emanate from the interplay of additional financial, fiscal, industrial and innovation policies to address five societal challenges, forming the EU's Missions for the next decade. As an integral part of the long-term Horizon Europe program, these Missions, whose implementation the EIB is committed to supporting, further widen the focal areas to include health as they encompass conquering cancer, seeking climate-neutral and smart cities, ensuring adaptation to climate change, promoting healthy oceans, and protecting soil health and food (Mazzucato, 2019). Hence, the EIB has departed once again from quasi-mono-focal climate endeavors to maintaining not only its multi-focal activity but also its multi-role engagement, covering all four roles in the typology developed by Mazzucato and Penna (2015), which is associated with the different types of investment support provided by state investment banks. These roles range "from a countercyclical role by providing finance throughout the swings of business cycles, to a capital development role by financing infrastructure, to a venture capitalist role and a mission-oriented role by acting as 'investor of first resort' to create new technological and industrial landscapes" (Mazzucato \& Mikheeva, 2020, p. 25). Albeit not being incipiently conceived as a "first responder," the new EU Missions' political and economic priorities see this EIB role particularly strengthened in the future. This role fits well with the EIB's increasing politicization process (Mertens \& Thiemann, 2018, 2019), its ambitions to develop into a policy-making EU body (Kavvadia, 2021b), and its tendency for more strategic interventionism and market-shaping activities (Clifton et al., 2021), including industrial policy (Griffith-Jones \& Naqvi, 2020). This ambition, which surfaced in EIB president Hoyer's foreword in the Mazzucato and Mikheeva (2020) report, is a further tell-tale sign of the EIB's policy-making aspirations. President Hoyer, in his brief foreword, advocated for the EIB's policy-making capabilities primarily through an advisory role and secondarily through its financing capacity when stating that the EIB "as the EU's investment bank, .. . is well placed to act as trusted adviser [emphasis mine] and financier in seeking to address the five societal challenges or Missions" (Mazzucato \& Mikheeva, 2020, p. 8). He considered that the report can showcase the EIB's value-added policy-making as it "rightly highlights the importance of the EIB's advisory services [emphasis mine] in delivering the transformative change demanded by the Missions that are anything but business as usual." On the contrary, in her foreword, Mazzucato referred to the EIB's stakeholder management in the bank's policy implementation role and "the way(s) in which the European Investment Bank can structure its activities to form a dynamic process of crowding in private sector investments" (Mazzucato \& Mikheeva, 2020, p. 6). The same line is also reflected in the foreword of EU Commissioner Gabriel, who stated that "the European Commission will mobilize its funding instruments to support the implementation of the missions. . . [and is confident that Commission and EIB can use the report] as a basis for cooperation to make missions a success" (Mazzucato \& Mikheeva, 2020, p. 9).

However, departing from the divergent stakeholder angles evidenced in the literature, the Commission's and the EIB's view on the bank's role in general and regarding equipoising climate finance with the post-pandemic boost can be best understood through a study of the EIB's main stakeholders' stances. Although officially considered in full harmony and complementary concerning the EU and EIB policies, these objectives entail an inbuilt "tension" briefly coined in this paper as restrictive and expansive, respectively, given that the 
"ability of one participant to gain his ends is dependent to an important degree on the choices or decisions the other participant [or participants] will make" (Schelling, 1980, p. 5). Even when aiming toward growth, as in the EU and the EIB cases, climate finance is inherently selective, restricting the sectors and investments eligible for funding to those complying with the EU taxonomy (EC, 2019a). Consequently, many projects or entire sectors do not qualify for financing and will be left behind as part of Europe's economic transformation. In contrast, the countercyclical approach that has historically been practiced in a post-crisis attempt to rebound the economy is more inclusive of supporting existing and planned economic activity as broadly as possible. It is protective of the existing production fabric to maintain employment levels and forward-looking for bolstering future growth through new investments that can be green or less green in the present dilemma. What are the interests of the EIB stakeholders? How do they stand vis-à-vis a more restrictive climate-linked, longerterm activity vs a more expansive and wide-broaching, countercyclical, shorter-term growth stimulus? How are their views affecting the EIB?

Even though the academic community is taking an increasing interest in the EIB from multiple perspectives, including the role of the bank in the COVID-19 all-round crisis with health, economic and social implications (Clifton, Díaz-Fuentes, Howarth, \& Kavvadia, 2020; Griffith-Jones \& Naqvi, 2020; Mertens, Rubio, \& Thiemann, 2020), the present paper investigates a new and topical subject concerning the challenge faced by the bank to equipoise climate finance with a post-pandemic boost. This dilemma occurred a few months after the EIB's self-anointment as the first international climate bank-ending its fossil fuel lending after 2021 and restricting its activity to green investments. Since then, the EU has solicited the bank to pay its share in containing the effects of the pandemic and supporting the economic rebound within a wide range of sectors, including some less green areas but possibly seen as useful for maintaining jobs and weathering the recession. Thus, caught between the clashing rocks of the market and the political context, the EIB is, due to its dual nature as an EU body and a bank operating in the market, called to balance competing political and economic objectives. Navigating treacherous waters, the bank is attempting to equipoise climate finance with a post-pandemic boost, balancing out its interests with those of its major stakeholders through the playing of multiple roles.

This article builds on existing secondary academic material and primary sources, including the EIB's publicly available activity and financial reports, speeches, and press releases to conceptualize the EIB stakeholders' set-up and governance. This constitutes the study's main scholarly contribution. In the next section, the article conceptualizes the EIB's stakeholder governance; in section three, it analyzes the stance of the EIB's major stakeholders on the bank's combined efforts for green growth and post-pandemic rebound, while major observations are summarized in the concluding section.

\section{Theorizing stakeholder governance and conceptualizing the EIB's stakeholder set-up}

Agency theory has enabled the understanding of organizational set-ups focusing on the dynamics and relations between organizations and their environment, consisting of different parties whose particular interests are interconnected with the organization, concerning its governance, processes and structure (Freeman, 1984; Donaldson \& Preston, 1995). In the organizational context, however, the theory has predominantly focused on ownership, consequently neglecting governance and relations with many other stakeholders, who often have conflicting interests concerning the organization (Freeman, 1984; Barney, 2018; McGahan, 2020). Nonetheless, failing to attend to stakeholder interests can result in farreaching value loss for organizations, impacting even financial aspects (Richard, 2000; Cuypers, Koh, \& Wang, 2016; Carney, 2020). This is of salient pertinence to public banks
European
Investment
Bank 
FREP

1,2

(Barrowclough, Marois, \& McDonald, 2020; Marois, 2021b; Mertens, Thiemann, \& Volberding, 2021), such as the EIB.

Agency theory has been used to analyze the EIB through the principal-agent model (Liebe \& Howarth, 2019; Kavvadia, 2021b), through a stakeholder perspective (Mertens \& Thiemann, 2019), and through the theory of fields (Kavvadia, 2021a). Contingent to the organization and its contextual environment, agency theory and stakeholder analysis concern a dynamic process that must be revisited periodically to evidence changes concerning the current new European economic governance conditions. Beyond external factors, such as the EU's development of a new fiscal capacity confirmed at the EU Council in December 2020, is the fermentation around a series of new policy decisions concerning the next programming period, and the specific new European Missions and policy directionsthese conditions have also been shaped by the EIB itself, being an EU body and a bank, through its policies and activity, its "pivot" to the climate in 2019 being a salient example. In this manner, the EIB influences both EU governance and the market, respectively. Therefore, acknowledging that "governance structures, or conceptions of control, refer to sets of ideas and rules that structure inter-and intra-firm" (Fligstein \& Maria-Dita, 1996, p. 7) allows for the understanding of the EIB as an actor within the "collective dynamics" of its relations with its major stakeholders (Schelling, 1984), such as other EU governance counterparts and market players. The analysis of the actors-who, through their policies, activity and preferences, impact the EIB's contextual set-up-elaborates on both sides of the bank's dual nature, as an institution acting within the EU governance constellation and as a bank operating within the market, interacting with its stakeholders for studying what is "at stake."

The EIB stakeholders fall into three categories: first, the institutional stakeholders, divided into major players in the EIB stakeholder governance set-up, such as the EU member states (EIB shareholders), the European Commission (one of the three central EU policymaking institutions), the European Parliament (the EU's legislative and democratic control institution) and minor players-other EU institutions with less interaction and influence on the EIB; second, market stakeholders, with predominant players being the EIB borrowers and investors in the capital markets, other banks, including peer multilateral development banks (MDBs), regional development banks (RDBs), national development banks (NDBs), and other banks participating or concerned by the EIB's lending and borrowing; and third, the civil society, including the general public and society segments expressed in organized forms through non-governmental organization (NGOs). In this sociology of markets' perspective, and regarding markets as loci of exchange, cooperation and antagonism among rational actors striving to fulfill a specific purpose (Hodson \& Peterson, 2017), the EIB's dilemma of equipoising climate finance with a post-pandemic boost is analyzed regarding the varying interests of its stakeholders. The aim is to identify their stances and which of the two alternative dilemma directions they wish the EIB to pursue.

The current contextual conditions influence stakeholder stances on the EIB's double-axis activity for containing the twin climate and pandemic crises, and possibly also accentuate conflicting interests for three main reasons: first, new actors enter into the stakeholder set-up, such as first-time borrowers or investors with new profiles; second, there is a change in the relative "power" of stakeholders to shape the set-up and influence the EIB, as in the case of the European Parliament, the Commission or the NGOs; and third, stakeholders adapt to the overarching political, economic and social environment. As a result of the crisis, social pressure and preferences are skewed toward more climate or more "business as usual" as long as it provides an anticyclical impetus. In the current situation, many new actors are entering the EIB stakeholder set-up individually, such as borrowers, lending rivals, investors and issuance competitors or peers. The increased number, however, does not alter the generic typology of stakeholder categorization. However, the relative "power" and contextual adaptation influence stakeholder interests and governance set-up because of broad, varying 
reasons, including the following: (1) the pandemic's impact is characterized by pronounced sectoral and geographic asymmetries (Bunde et al., 2021), with wide variations between, for instance, low-vs high-contact economic sectors (Das, Lian, Magistretti, Pugacheva, \& Wingender, 2021), with some manufacturing areas "experiencing supply destruction not mere disruption" (Carney, 2020), and some countries, mainly in Southern and Eastern Europe, having been hit much stronger (Eurostat, 2021); (2) the largest and most economically significant part of the NGEU consists of grants within the new resilience facility (RF) and preexisting programs, which will obviously be preferred due to their concessional nature over loans, with the latter serving mainly the economically weaker countries, which face relatively higher borrowing costs in the capital markets; (3) the timing of the NGEU funds-outflow favors the countries with fiscal surpluses-as some three-quarters of the pay-outs will be effective in 2023, while countries in need are offered bridge-financing in the form of EU loans, with repayments in the period 2028-2058, which can possibly be supplemented with additional EIB loans; (4) the EU loans to the fiscally strained European economies-mostly the same as those that were hit by the last global economic and financial crisis-are sourced through the proceeds of 30 -year Eurobonds, to be issued by the Commission. With a planned issuance of EUR1tn over the next five years being more than three times higher than the EIB's planned issuance in the same period (Ainger \& Nardelli, 2021), the Commission has consequently become an important EIB competitor in the capital markets, which might strain their relations. Other reasons are (5) that the European financial response package falling short of an economic recovery (Picek, 2020) will increase competition among countries and project promoters, who, in "sharing the pie," might prioritize covering their most urgent financing needs instead of undergoing longer-term climate-related transformational adjustments, and (6) despite that the twin crises-in the sense of combined climate and pandemic-related recession, and not in the usual solely monetary-related definition-have changed the ways that public and private sectors balance risk and resilience (Carney, 2020), the EIB's response utilizes the same "old" fund-distribution mechanisms, predominantly favoring its network of intermediating financial institutions for channeling its funds to small and medium-sized enterprises (SMEs) (Clifton et al., 2020). However, the banking sector is currently constrained by the overarching borrowing capacity of their sovereigns, making more evident the "need to level the playing field" (Mertens et al., 2020, p. 8). Furthermore, calls have been made for "a greater focus on the final beneficiaries of projects rather than on the private financial intermediaries themselves" (Clifton et al., 2020; Griffith-Jones \& Naqvi, 2020); hence, there is yet another reason (7), which is that the EIB's path-dependent approach is not tailored enough to the current context, which, unlike the situation in the late 2000s, the "black swan" has strongly impacted the real economy rather than the financial sector. Consequently, there is no need to continue on the financialization and intermediation path (Clifton et al., 2020), which privileges funds channeling through the banking sector (representing more than one-third of the aggregate annual EIB lending and some $80 \%$ of the EIB's response to COVID) to reach SMEs, while also providing support and treasury comfort to financial intermediaries. The preponderance of intermediated funding of SMEs might divide stakeholders on issues of opacity and lack of (Clifton et al., 2020; Griffith-Jones \& Naqvi, 2021). Although it makes no sense to want everything and its opposite at the same time, the intermediation is expected to raise further concerns concerning greenwashing prospects $(\mathrm{CB}, 2021)$, despite having been tolerated by stakeholders-including those insisting on transparency, such as the European Parliament (EP, 2001)-during the financial crisis of the late 2000s.

In the context of fluid "relative-power" dynamics, combined with diverging stakeholder interests, the EIB is naturally involved in stakeholder governance management to influence developments, contain eventual risks and threats, and increase its reputation and relevance. The EIB's stakeholder governance set-up reflects the bank's dual nature, as an EU body and a bank, with its principal stakeholders falling into three categories: (1) institutional-related, (2)

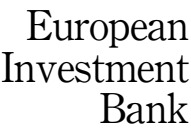

175 
FREP

1,2

176

market-related and (3) civil society, whose interest scales up in parallel with the EIB's activity and clout, as a public bank. These three stakeholders interact among themselves and the EIB in a dynamic process, framing and influencing each other and the bank. The dynamics of the stakeholder governance forces pictured in Figure 1 apply to the EIB and other public banks.

The theory of stakeholder governance has been approached in the bibliography from two distinct angles. The first is the longitudinal angle, which differentiates the bargaining process based on whether it takes place once, with reconciliation reached in a single negotiation (Krishna \& Serrano, 1996), or repeated over time, in a series of negotiations reconciled among stakeholders in a sequential manner (Machlup \& Taber, 1960). The second is the participatory angle, which differentiates the bargaining process between bilateral (Machlup \& Taber, 1960) and forum-oriented ways of conducting (Wang, He, \& Mahoney, 2009; Klein, Mahoney, McGahan, \& Pitelis, 2012; Hoskisson, Gambeta, Green, \& Li, 2018). Building on these two angles and viewing stakeholder governance management as the outcome of bargaining among the actors of the stakeholder governance structure, who pursue diverging and possibly conflicting political, economic and social interests, one can develop a generic framework of process-related patterns. This framework differentiates processes based on the type of bargaining form followed, tending to be: first, private, with individual or group consultations running in parallel or sequentially among actors in a confidential manner and with outcomes that are equally predominantly private, as in the case of the EIB with its borrowers, investors, and often with the EU member states; and second, public, with negotiations within forums, where conflicts among stakeholders can be addressed collectively, and outcomes are in the public domain, as seen in the case of the NGOs or the European Parliament. In other words, stakeholder governance management deploys bargaining forms that range from more private and individual to more public and collective processes, whereby the outcomes tend to remain either private or become public.

Consequently, stakeholder governance can range from a "privacy sphere" end to a "transparency sphere" end, and stakeholder governance activity can be placed between these two extremes, depending on whether primary bargaining and primary outcomes are predominantly intended to be private or public. In the framework provided illustratively in Figure 2, stakeholder governance involves a "privacy sphere" and a "transparency sphere." Any organization managing its stakeholder governance engages in activities that fit in

Figure 1.

Stakeholder governance: EIB forces dynamics

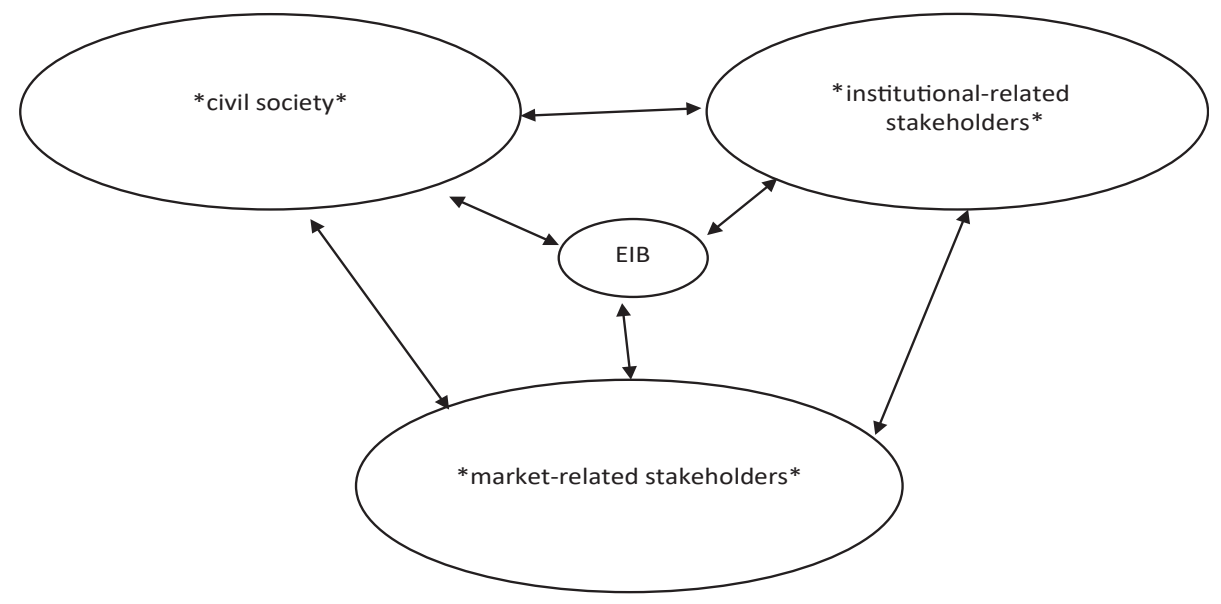

Source(s): Author's work 


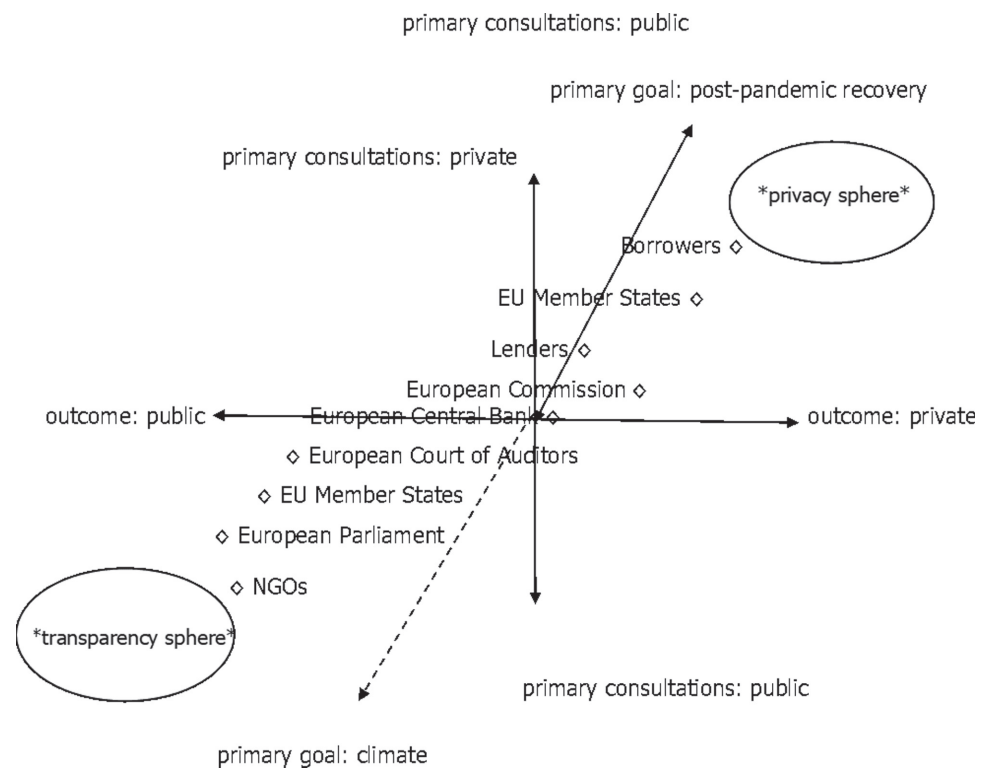

Source(s): Author's work

European

Investment

Bank

177

between these two extremes and mark its unique "footprint," encompassing the stakeholders and the way negotiations with every one of them occur.

\section{Between Scylla and Charybdis?}

The EIB stakeholders' stances on the particular dilemma under investigation range between climate action and post-pandemic recovery. Both climate and recovery objectives are significant in political and economic terms. Their synchronous attainment is precluded because they imply diverging routes of action. Suffering from a paucity of convergence and leaving ample room for dissonance, participants' stances influence the EIB and how the bank manages their views on equipoising climate finance with a post-pandemic boost in a dynamic process within the bank's stakeholder governance framework. In its "balancing act," the EIB is challenged, as if navigating between Scylla and Charybdis.

A qualitative and quantitative analysis of primary EIB documentation and activity metrics reflects the bank's institutional, market-related and civil society stakeholders' stances. Additionally, this analysis probes stakeholders' positioning regarding their stances on the restrictive vs expansionary dilemma on the generic framework by adding a third dimension to the generic framework. This section sketches the profile of the major stakeholders falling into all three categories seen above, which have been retained as the most relevant to the EIB dilemma, briefly reports their dilemma-related preferences, and tries to understand the approach that the EIB will follow in trying to equipoise climate and post-crisis lending. The bank appears to follow the prioritization approach (McGahan, 2020) to manage its stakeholder governance. In this vein, the EIB prioritizes its stakeholders based on their importance for its vital interests and its existence, mainly based on their relative "power" over the bank (Kavvadia, 2021a, b) and less based on legitimacy or urgency (Mitchell, Agle, \& Wood, 1997). The European Court of Auditors (ECAs), which, although legitimate, is not privileged, and NGOs, which, when often calling for urgent activity adjustment by the EIB, are not prioritized, are cases in point. 
FREP

1,2

Regarding importance, the EU member states, being the EIB's shareholders and prime beneficiaries associated with $90 \%$ of its lending and $70 \%$ of its borrowing activity, rank first among stakeholders in the bank's readiness to satisfy their requests. Serving their interests and needs is the EIB's key remit parameter and a prerequisite for continued relevance. In return, the bank's shareholders have counter-offered continuous support through successive capital increases, placing the EIB as top-of-the-list on shareholding support among RDBs (Kavvadia, 2021a). Their continuous support can certainly be seen as recognition of the bank's services supporting their interests.

In the present dilemma, the views of member states are shared. Even those that have had a lead role in the EIB's "pivot" to climate, such as France (Krukowska, 2019), are under national pressure to maintain business and employment levels and may, consequently, either privately actively seek or tolerate an expansive EIB route to keep their home economies afloat. The way negotiations take place within the EIB stakeholder governance framework, which tends to be private, allows for a divergence to their official proclamations (Fleming, 2021), leaving a certain degree of "laissez-faire" as a boon for the recovery of their economies. The position of the Commission goes to the antipode of the mixed collective stance of the member states. Commissioner von der Leyen's run for office, having the EGD as her "personal mark" and flagship project, has ownership of the initiative, and its success will shield the success of her term. This explains to a large extent why the Commission put climate at the center of all of its subsequent initiatives, ranging from strategic autonomy and development assistance to its bold post-pandemic recovery. The Commission is an increasingly important stakeholder of the EIB, as their activities become ever closer and interlinked, blending budgetary resources with EIB loans. The Commission is covering a major part of the EIB's excess risk for all recent European economic initiatives, in which it has called the EIB to participate.

Additionally, the two emerge latently as competitors, especially in the capital markets, as the Commission starts to roll out a new massive Eurobond issuance program. The competition will intensify existing tensions of a typical principal-agent situation, characterized by a "cultural gap" (EP, 2016, p. 103) and "discontent" (Mertens \& Thiemann, 2019, p. 21). These tensions partly explicate the Commission's calls for more transparency for achieving more control over the EIB.

The European Parliament is currently "greener" than ever, and so are its official deliberations. However, its members are sensitive to their constituencies' needs for recovery. Because of the untoward and successive waves of economic damage triggered by a series of lockdowns, the European Parliament Members face increasing calls to curb joblessness, which could eventually flout their green assertions. Consequently, when outside public fora, in more private consultations, members of the Parliament might send mixed signals to the EIB regarding the way to go about the dilemma. Nonetheless, being among the stakeholders who compel the EIB into more transparency of its activity, the European Parliament remains among the first to call the EIB into account if any of the bank's activities deviate from the official European objectives. The EIB forms, with its peers, a typical RDB field in which the bank enjoys an incumbent position.

Notwithstanding that cooperation among peers is on a win-win basis to share market, expertise and risk (Kavvadia, 2021a), some of the RDBs have been caught unaware by the EIB's "pivot" to climate, as they had themselves equally been green or in some cases even greener than the EIB (Wright, Hawkins, Orozco, \& Mabey, 2018). Largely, RDBs have followed suit on climate-lending thresholds following the EIB's example (FiC, 2020), and most of them have signed a common declaration to align with the Paris Agreement. However, not belonging to a supranational structure such as the EU, most RDBs are freer to form policy and are subject to lighter scrutiny than the EIB. Although demonstrating a green stance, they can easily profit and take on their books left-out, less green projects for three main reasons: 
first, to increase their volume of operations by satisfying unmet demand; second, to more comfortably manage their risk profiles, as they do not enjoy the EIB's privilege of sharing risk mostly with the Commission; and third, by leaving the EIB to restrictive lending by "playing" the international climate bank-some of them can ensconce themselves in other key roles, such as development (Brunsden \& Khan, 2018), with a broad-broaching approach to lending. Investors have shown a positive stance on climate in the capital markets since the EIB pioneered the first-ever green bond in 2007. The bank has emerged as the largest green bond issuer through its continuous support, with more than EUR16 billion issued in the green format in 11 different currencies (EIB, 2017, p. 3). Despite their positive stance on climate, investors are rather interested in yields. With green bonds not offering premia, in a period of increased competition in the capital markets following the entry of the Commission in this segment, the EIB might experience relatively declining market shares for its general issuance, with its green bonds averaging only some $6.5 \%$ of the EIB's yearly issuance program. The EIB borrowers have demonstrated an increased appetite for green investments, with climaterelated lending, therefore reaching an annual average of some $25 \%$ of the bank's aggregate yearly activity volume until 2018 and some $40 \%$ thereafter. Seeing market advantages or aiming at avoiding market losses due to the European green industrial policy, a good number of traditional brown EIB borrowers, such as energy producers, have turned to climate, promoting green projects, leaving, however, the door wide open for greenwashing at the level of individual projects or whole sectors (CB, 2020a, b). This risk tends to increase with postCOVID-19 rebound lending (CB, 2020c), as fears are being expressed about possible creative statistics, coined in RDB parlance as "window-dressing" of results (Clifton et al., 2020).

EIB borrowers invest in areas where they see profit prospects, and some are already taking positions given the broad-ranging EU green industrial policy. Amidst the pandemic Armageddon, though, these are not the majority of investors. Most of them are quite contrarily currently fighting for survival and seeking quick fixes to stay in business with countercyclical, expansive, broad-broaching finance while mostly leaving their eventual green or brown investment plans for more opportune times. The EIB providing fixed-assetrelated project loans at a good rate, but at market cost, cannot incentivize investors and alter their investment or non-investment plans on pricing alone (EIB, 1999, p. 2), as grant finance could eventually achieve in a logic of consequentialism (see Figure 3).

The restrictive-expansive dichotomy has facilitated the study of the EIB stakeholders' governance set-up and preferences concerning future EIB activity. Although stakeholders' positioning is dynamic and scalable, the analysis showed a rift among different stakeholders at different levels and facets. Their preferences often change direction based mainly on the negotiating and outcome treatment modus ranging from the public to the private sphere. Moreover, with politics trumping economics, there is a marked deviation between institutional- and market-related stakeholders. Future EIB activity is intimately linked to the stances of its stakeholders on the dilemma and on the way it is going to manage them; hence, the latter aspect is equally worth delving into. The theory of stakeholder governance distinguishes two main approaches in stakeholder governance management: first, the prioritization of stakeholders (Simon, 1952; Barney, 2018; McGahan, 2020) based on their importance to the organization, which consequently also entails the prioritization of their interests; and second, the conflict resolution methods, without, however, providing recommendations for established theoretical frameworks and leaving the methods rather on organizational judgment (Nickerson \& Zenger, 2002; Alvarez \& Barney, 2007). The EIB has historically followed the prioritization approach (Kavvadia, 2021a), whereby member states' interests must be served first. The EIB's "pivot" to climate was also the result of such an alignment with member states' interests, enabling the bank to mark its relevance in the new European economic governance set-up in the making (Kavvadia, 2021b) while not disrupting its modus operandi. With member states' mixed messages, in the case of the
European
Investment
Bank

179 
FREP

1,2

180

Figure 3.

Stakeholder governance framework: EIBrestrictive vs expansive dilemma

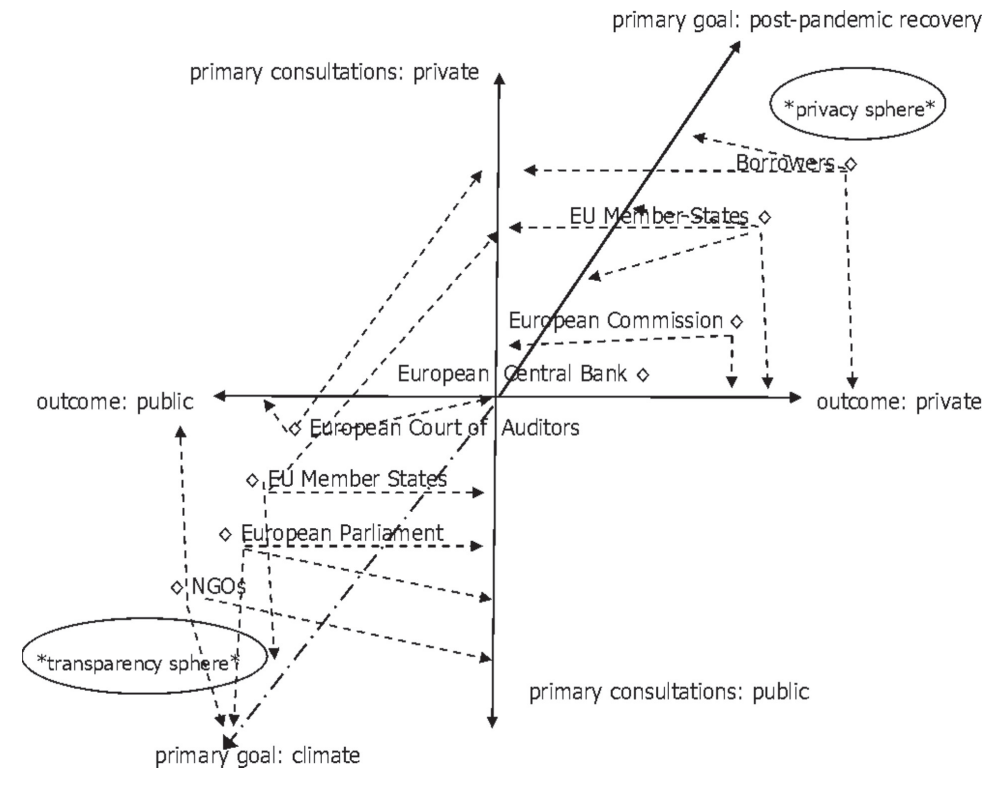

Source(s): Author's work

expansive-restrictive dilemma, the EIB is expected to follow the same blurred focus approach in its future lending, verifying the concerns expressed by NGOs.

\section{Conclusions}

A few months after the pronouncement of the EGD, and upon the outbreak of the COVID-19 health and economy crisis, the EU called its long-term financing bank to support both urgent needs to ensure transformative green growth in the long run and a post-pandemic quick economic rebound in the short term. Nevertheless, devastating economic actors in need of short-term assistance fall within many sectors, including some less green ones. Additionally, the priorities of many private and public sector companies are skewed toward survival over future perspectives. Thus, while the EU calls for a unifying approach, blending climate and pandemic responses, economic actors appear divided. The urgency and preferences shape their diverging stances at an organizational level toward a greener, more innovative, and more competitive future and remaining afloat through urgent countercyclical support.

Moreover, at a national level, the EU member states appear equally divergent in their stances on the dilemma of climate-countercyclical rebound action. Therefore, it is of utmost importance to contain a series of economic and social hazards that can be expected at different time lapses, resulting in the devastation of their financial and real economies if the rebound does not take place. Such an economic catastrophe would eventually also influence their future climate prospects.

Segregating these two diverging activity agendas related to the rebound vs climate activity dilemma facilitated the analysis of the EIB's stakeholder governance set-up and the relevant stances of its major stakeholders. Additionally, the article conceptualized a theoretical framework of stakeholder governance, on which the stakeholders can indicatively be positioned, for a clearer representational overview of their standing. The framework demonstrates, in a visual way, what the qualitative analysis of the stakeholders showed. It 
depicts that views of pursuing these two seemingly contradictory objectives of exclusively restricting the EIB's activity in green funding or boldly and urgently expanding its activity to achieve an economic rebound through a broad impact in the real economy are diverging at all fronts. The stakeholders reflecting the EIB's institutional side have diverging stances, which in turn conflict with the stakeholders' interests, mirroring the EIB's bank side, which includes the EIB's borrowers, lenders and peers. The only clear stance is that of civil society, where climate prevails.

Furthermore, this article confirms existing findings that the EIB follows the prioritization approach to manage its stakeholders' governance. In other words, transcending the forces influencing the stakeholders' governance to understand its rationale boils down to knowing or determining who calls the shots. Given that the stances of the EU member states, which are the EIB's top-ranking stakeholders, are unclear and deviating, the EIB has leeway in skewing toward the post-COVID restart. Against a backdrop characterized by the paucity of a comprehensive and integrated approach from the member states and in contradistinction to the Commission's calls, the EIB, due to idiosyncratic reasons for balancing the two agendas, has the chance to keep up with its activity volume, which would eventually diminish, in the case of restrictive lending. As the EIB's "pivot" to climate has been decided on political rather than business grounds and based on EU member states' stances, the EIB's stakeholder governance analysis confirmed that the political agenda trumps the economic one. The diverging interests of member states and the rift between institutional and market-related stakeholders increases the risk of the NGOs' feared greenwashing, which does not bode well for the EIB's future climate activity.

\section{References}

Ainger, J., \& Nardelli, A. (2021). EU lays out $\$ 1$ trillion debt plan to challenge treasuries. Bloomberg. Available from: https://www.bloomberg.com/news/articles/2021-04-13/eu-to-lay-out-1-trilliondebt-plan-to-start-rivaling-treasuries (accessed 13 April 2021).

Alvarez, S. A., \& Barney, J. B. (2007). Discovery and creation: Alternative theories of entrepreneurial action. Strategic Entrepreneurship Journal, 1(1), 11-26.

Barnes, P. M., \& Hoerber, T. C. (2013). Sustainable Development and Governance in Europe: The Evolution of the Discourse on Sustainability. Abingdon: Routledge.

Barney, J. B. (2018). Why resource-based theory's model of profit appropriation must incorporate a stakeholder perspective. Strategic Management Journal, 39(1), 3305-3325.

Barrowclough, D. V., Marois, T., \& McDonald, D. A. (2020). Public banks matter at a time of COVID19. In McDonald, D. A., Marois, T., \& Barrowclough, D. V. (Eds), Public Banks and Covid-19: Combating the Pandemic with Public Finance (pp. 1-25). Kingston, Geneva, and Brussels: Municipal Services Project, UNCTAD, and Eurodad. Available from: https:// publicbankscovid19.org/images/PDF_FILES/Public_Banks_and_Covid19_-_Full_Book.pdf (accessed 1 May 2021).

Brunsden, J., \& Khan, M. (2018). France and Germany call for shake-up of EU development banks. Concern that poor co-ordination between EIB and EBRD leads to overlap. Financial Times, Available from: https://www.ft.com/content/3847f9ec-c5bc-11e8-8167-bea19d5dd52e (accessed 1 October 2018).

Bunte, T., Eisentraut, S., Hartmann, L., Carr, R., Hammelehle, J., Kabus, J., .. Mudie-Mantz, A. (2021). Between states of matter: competition and cooperation. Munich: Munich Security Report. Available from: https://securityconference.org/publikationen/munich-security-report-2021/ (accessed 15 July 2021).

Carney, M. (2020). Putting values above valuations. The Economist. 18 April, p. 54, Available from: https:/www.economist.com/by-invitation/2020/04/16/mark-carney-on-how-the-economy-mustyield-to-human-values (accessed 18 April 2020).

\section{European Investment Bank}


FREP

1,2

182

Counter Balance (CB) (2020a). The EU climate bank - Greenwashing or a banking revolution?. June 2020, Brussels, Counter Balance. Available from: https://counter-balance.org/media/episode-8eu-climate-bank (accessed 15 July 2021).

Counter Balance (CB) (2020b). Too soon to call the EIB the "EU climate bank". July 2020, Brussels, Counter Balance. Available from: https://counter-balance.org/publications/too-soon-to-call-theeib-the-eu-climate-bank (accessed 15 July 2021).

Counter Balance (CB) (2020c). The EIB as EU climate bank: Only halfway there. An analysis of the new EIB climate roadmap and the way forward. December 2020, Brussels, Counter Balance. Available from: https://counter-balance.org/publications/eib-as-eu-climate-bank-only-halfwaythere (accessed 15 July 2021).

Counter Balance (CB) (2021). The European green deal: Reclaiming public investments for a real socioecological transformation. Available from: https://counter-balance.org/publications (accessed 15 September 2021).

Clifton, J., Diaz-Fuentes, D., \& Revuelta, J. (2014). Financing utilities: How the role of the European investment bank shifted from regional development to making markets. Utilities Policy, 29(1), 63-71.

Clifton, J., Diaz-Fuentes, D., \& Gómez, A. L. (2018). The European investment bank: Development, integration, investment? Journal of Common Market Studies, 56(4), 733-750.

Clifton, J., Díaz-Fuentes, D., Howarth, D., \& Kavvadia, H. (2020). The role of the European Investment Bank in times of COVID-19 In McDonald, D. A., Marois, T., \& Barrowclough, D. V. (Eds), Public Banks and Covid-19: Combating the Pandemic with Public Finance (pp. 135-148). Kingston, Geneva, and Brussels, Eurodad: Municipal Services Project, UNCTAD. Available from: https:// publicbankscovid19.org/images/PDF_FILES/Chapter_6_-_EIB.pdf (accessed 1 May 2021).

Clifton, J., Diaz-Fuentes, D., \& Howarth, D. (2021). Regional development banks in the world economy. In Clifton, J., Díaz Fuentes D., \& Howarth, D. (Eds), Regional Development Banks in the World Economy (pp. 1-30). Oxford: Oxford University Press.

Cuypers, I. R., Koh, P. S., \& Wang, H. (2016). Sincerity in corporate philanthropy, stakeholder perceptions and firm value. Organization Science, 27(1), 173-188.

Das, S., Lian, W., Magistretti, G., Pugacheva, E., \& Wingender, P. (2021). After-effects of the COVID-19 pandemic: Prospects for medium-term economic damage. In World Economic Outlook: Managing Divergent Recoveries (pp. 43-61). International Monetary Fund Research Dept. International Monetary Fund. doi: 10.5089/9781513575025.081.

Donaldson, T., \& Preston, L. E. (1995). The stakeholder theory of the corporation: Concepts, evidence, and implications. Academy of Management Review, 20(1), 65-91.

Dyrhauge, H., \& Kurze, K. (Eds), (2021). Making the European Green Deal Work. EU Sustainability Policies at Home and Abroad. Abingdon: Routledge, (Forthcoming).

European Commission (EC) (2019a). Taxonomy technical report. Financing a sustainable European economy. Technical Expert Group on sustainable finance, Taxonomy Technical Report, June 2019. Available from: https://ec.europa.eu/info/sites/default/files/business_economy_euro/ banking_and_finance/documents/190618-sustainable-finance-teg-report-taxonomy_en.pdf (accessed 10 July 2019).

European Commission (EC) (2019b). Communication from the Commission to the European Parliament, the European Council, the Council, the European Economic and Social Committee and the Committee of the Regions. The European Green Deal, 11 December 2019. Available from: https://ec.europa.eu/info/sites/default/files/european-green-deal-communication _en.pdf (accessed 2 January 2020).

European Commission (EC) (2021). The EU's 2021-2027 long-term budget \& next generation EU. Available from: https://op.europa.eu/en/publication-detail/-/publication/d3e77637-a963-11eb9585-01aa75ed71a1/language-en (accessed 2 May 2021). 
European Investment Bank (EIB) (1999). Annual Report 1998. Luxembourg: EIB. Available from: https://www.eib.org/en/publications/annual-report-1998 (accessed 15 June 2021).

European Investment Bank (EIB) (2017b). Speech at the International Capital Market Association (ICMA). Luxembourg, 4 May 2017. Available from: https://www.eib.org/en/press/all/2017-112eib-president-werner-hoyer-calls-on-financial-industry-to-work-together-and-support-inclusivegrowth (accessed 21 May 2017).

European Investment Bank (EIB) (2019). EU Bank launches ambitious new climate strategy and energy lending policy [press release]. 14 November. Available from: https://www.eib.org/en/ press/all/2019-313-eu-bank-launches-ambitious-new-climate-strategy-and-energy-lending-policy (accessed 15 December 2019).

European Parliament (EP) (2001). Final report on action taken on the EIB annual report. (2000/ 2173(INI)) Committee on Economic and Monetary Affairs, Rapporteur, Alain Lipietz, A5-0000/ 2001, 25 January 2001.

European Parliament (EP) (2016). Research for REGI Committee - Review of the role of the EIB group in European cohesion policy. Directorate General for Internal Policies. Policy Department B: Structural and Cohesion Policies Regional Development, IP/B/REGI/IC/2015-019 March 2016. PE 563.410 EN.

Eurostat (2021). Euroindicators 66/2021. 8 June. Luxembourg: Eurostat. Available from: https://ec. europa.eu/eurostat/documents/2995521/11563119/2-08062021-AP-EN.pdf/eead4cc5-f4f2-a0879ded-a1b15bf2394a?t=1623140343558 (accessed 15 June 2021).

Finance in Common (FiC) (2020). Joint declaration of all public development banks in the world. Signed at the Finance in Common Summit, 12 November 2020. Available from: https:// financeincommon.org/sites/default/files/2020-11/FiCS\%20-\%20Joint $\% 20$ declaration $\% 20$ of $\%$ 20all\%20Public\%20Development\%20Banks.pdf (accessed 15 September 2020).

Fleming, S. (2021). These countries are leading the way on a post-pandemic green recovery. World Economic Forum, 29 April. Available from: https://www.weforum.org/agenda/2021/04/ countries-leading-post-pandemic-green-recovery/ (accessed 15 June 2021).

Fligstein, N., \& Maria-Dita, I. (1996). How to make a market: Reflections on the attempt to create a single market in the European union. American Journal of Sociology, 102(1), doi: 10.1086/230907.

Freeman, R. E. (1984). Stakeholder Management: Framework and Philosophy. Mansfield, MA: Pitman.

Griffith-Jones, S., \& Naqvi, N. (2020). Industrial policy and risk sharing in public development banks lessons for the post-COVID response from the EIB and EFSI. GEG working paper. The Global Economic Governance Programme, University of Oxford, 143, Available from: https://www.geg. ox.ac.uk/sites/geg.bsg.ox.ac.uk/files/2020-07/GEG\%20WP\%20143\%20July \% 202020\% 20Industrial $\% 20$ policy $\% 20$ and $\%$ 20risk $\% 20$ sharing $\% 20$ in $\% 20$ public $\% 20$ development $\%$ 20banks.pdf (accessed 19 November 2020).

Griffith-Jones, S., \& Naqvi, N. (2021). Leveraging policy steer? Industrial policy, risk-sharing, and the european investment bank. In Mertens, D., Thiemann, M., \& Volberding, P. (Eds), The Reinvention of Development Banking in the European Union: Industrial Policy in the Single Market and the Emergence of a Field. Oxford Scholarship Online, March 2021. doi: 10.1093/oso/ 9780198859703.001.0001.

Hodson, D., \& Peterson, J. (2017). Theorizing EU institutions: Why they matter for politics and international relations. In Hodson, D., \& Peterson, J. (Eds), Institutions of the European Union (4th ed.). Oxford: Oxford University Press.

Hoskisson, R. E., Gambeta, E., Green, C. D., \& Li, T. X. (2018). Is my firm-specific investment protected? Overcoming the stakeholder investment dilemma in the resource-based view. Academy of Management Review, 43(1), 284-306.

Kavvadia, H. (2020). From a policy bank to a crowding-in bank: The development of the European investment bank in the last ten years, as seen through its business model. Croatian Regional Development Journal, 1(1), 30-43.

\section{European Investment Bank}

183


FREP

1,2

184

Kavvadia, H. (2021a). The European investment bank and the Asian infrastructure investment bank: Incumbents and challengers in the field of regional development banking. In Clifton, J., Díaz Fuentes, D., \& Howarth, D. (Eds), Regional Development Banks in the World Economy. Oxford: Oxford University Press.

Kavvadia, H. (2021b). The European Investment Bank's quantum leap to become the world's first international climate bank. Politics and Governance, 9(2), 185-195.

Klein, P. G., Mahoney, J. T., McGahan, A. M., \& Pitelis, C. N. (2012). Who is in charge? A property rights perspective on stakeholder governance. Strategic Organization, 10(2), 304-315.

Krishna, V., \& Serrano, R. (1996). Multilateral bargaining. Review of Economic Studies, 63(1), 61-80.

Krukowska, E. (2019). Macron's dream of a climate bank gets boost from new EU leader. Bloomberg. Available from: https://www.bloomberg.com/news/articles/2019-07-12/macron-s-dream-of-aclimate-bank-gets-boost-from-new-eu-leader.12.07 (accessed 12 July 2019).

Liebe, M., \& Howarth, D. (2019). The European Investment Bank as policy entrepreneur and the promotion of public-private partnerships. New Political Economy, 25(2), 195-212.

Machlup, F., \& Taber, M. (1960). Bilateral monopoly, successive monopoly, and vertical integration. Economica, 27(1), 101-119.

Marois, T. (2021a). A dynamic theory of public banks (and why it matters). Review of Political Economy. doi: 10.1080/09538259.2021.1898110.

Marois, T. (2021b). Public Banks: Decarbonisation, Definancialisation, and Democratisation. Cambridge: Cambridge University Press.

Mazzucato, M. (2019). Governing missions in the European union. Report for the European Commission. Available from: https://ec.europa.eu/info/sites/info/files/research_and_innovation/ contact/documents/ec_rtd_mazzucato-report-issue2_072019.pdf (accessed 19 June 2020).

Mazzucato, M., \& Mikheeva, O. (2020). The EIB and the New EU Missions Framework. Opportunities and Lessons from the EIB's Advisory Support to the Circular economy. UCL Institute for Innovation and Public Purpose (IIPP). Policy Report (IIPP WP2020-17). Available from: https:// www.eib.org/attachments/press/eib-and-new-eu-missions-framework-report-18-nov-en.pdf (accessed 19 June 2021).

Mazzucato, M., \& Penna, C. (2015). Beyond Market Failures: The Market Creating and Shaping Roles of State Investment Banks. Working paper No. 831. Levy Economics Institute. Available from: http://www.levyinstitute.org/pubs/wp_831.pdf (accessed 19 November 2020).

McGahan, A. M. (2020). Where does an organization's responsibility end? Identifying the boundaries on stakeholder claims. Academy of Management Discoveries, 6(1), 8-11.

Mertens, D., Rubio, E., \& Thiemann, M. (2020). COVID-19 and the Mobilization of Public Development Banks in the EU. Policy paper No. 252, April 2020. Paris: Jacques Delors Institute. Available from: https://institutdelors.eu/en/publications/covid-19-and-the-mobilisation-of-publicdevelopment-banks-in-the-eu-2/ (accessed 2 May 2021).

Mertens, D., \& Thiemann, M. (2018). The European Investment Bank is becoming increasingly politicized. LSE Blog. Available from: https://blogs.lse.ac.uk/brexit/2019/02/20/the-europeaninvestment-bank-is-becoming-increasingly-politicised.12/02/2019 (accessed 2 May 2019).

Mertens, D., \& Thiemann, M. (2019). The politicization of the European investment bank? Managing hybridity and resource dependence in the European economic governance. In Paper Presented at the Conference "Analyzing the European Investment Bank: Interdisciplinary Approaches to Understanding the Past, Present and Future of the World's Biggest Lender", 10-11 July 2019. University of Luxembourg.

Mertens, D., Thiemann, M., \& Volberding, P. (2021). The making of a European field of development banking. In Mertens, D., Thiemann, M., \& Volberding, P. (Eds), The Reinvention of Development Banking in the European Union. Industrial Policy in the Single Market and the Emergence of a Field (pp. 1-33). Oxford: Oxford University Press. 
MišíkM., \& OravcováV. (Eds), (2021). From Economic to Energy Transition: Three Decades of Transitions in Central and Eastern Europe. London: Palgrave Macmillan.

Mitchell, R. K., Agle, B. R., \& Wood, D. J. (1997). Toward a theory of stakeholder identification and salience: Defining the principle of who and what really counts. Academy of Management Review, 22(1), 853-886.

Nickerson, J. A., \& Zenger, T. R. (2002). Being efficiently fickle: A dynamic theory of organizational choice. Organization Science, 13(2), 547-566.

Picek, O. (2020). Spillover effects from next generation EU. Intereconomics, 55(5), 325-331.

Richard, O. C. (2000). Racial diversity, business strategy, and firm performance: A resource-based view. Academy of Management Journal, 43(1), 164-177.

Schelling, T. (1980). The Strategy of Conflict. Cambridge, MA: Harvard University Press.

Schelling, T. (1984). Choice and Consequence: Perspectives of an Errant Economist. Cambridge, MA: Harvard University Press.

Simon, H. A. (1952). A comparison of organization theories. Review of Economic Studies, 20(1), 40-48.

Torney, D. (2019). Follow the leader? Conceptualizing the relationship between leaders and followers in polycentric climate governance. Environmental Politics, 28(1), 167-186.

Wang, H. C., He, J., \& Mahoney, J. T. (2009). Firm-specific knowledge resources and competitive advantage: The roles of economic- and relationship-based employee governance mechanisms. Strategic Management Journal, 30(2), 1265-1285.

Wright, H., Hawkins, J., Orozco, D., \& Mabey, N. (2018). Banking on Reform. Aligning Development Banks With the Paris Climate Agreement. Report. Berlin, Brussels, London, and Washington, DC: E3G. Available from: https://www.e3g.org/publications/banking-on-reform-aligningdevelopment-banks-with-paris-climate-agreement/ (accessed 2 May 2021).

\section{About the author}

Dr Helen Kavvadia is researcher in residence at the Institute of Political Science-University of Luxembourg. Prior to this, she was a senior adviser at the Communications Department of the European Investment Bank (EIB). She holds among others a $\mathrm{PhD}$ in Economics and Political Science from the Panteion University-Athens. Her research focuses on political economy and economic diplomacy, a topic she teaches at the University of Luxembourg, since 2017. Helen Kavvadia can be contacted at: helen.kavvadia@ext.uni.lu

For instructions on how to order reprints of this article, please visit our website:

www.emeraldgrouppublishing.com/licensing/reprints.htm

Or contact us for further details: permissions@emeraldinsight.com 